\title{
Menggunakan Stepwise Linear Regression Untuk Menentukan Faktor Yang Mempengaruhi Produktivitas Tenaga Kerja
}

\author{
Aswar Hanif \\ AMIK BSI Jakarta \\ e-mail: aswar.awf@bsi.ac.id
}

\begin{abstract}
Abstrak
Semakin lama masa kerja, semakin banyak pengalaman yang dimiliki seseorang atas pekerjaannya. Seorang yang memiliki tingkat kehadiran yang tinggi, dianggap sebagai pekerja yang baik. Kedua faktor ini membentuk asumsi bahwa masa kerja dan tingkat kehadiran, secara positif atau negatif, mempengaruhi produktivitas pekerja. Dikarenakan besarnya pengaruh produktivitas pekerja terhadap kesehatan sebuah perusahaan, kegiatan menganalisis produktivitas tenaga kerja perusahaan, seharusnya tidak didasarkan pada asumsi-asumsi, meskipun asumsi tersebut bisa diterima. Menggunakan Regresi Linier Berganda, sebuah model persamaan dihasilkan dari data-data mengenai tenaga kerja. Tapi, karena nilai Koefisien Determinasi yang dihasilkan kurang memuaskan, dilakukan analisis ulang terhadap data. Kali ini menggunakan Regresi Linier Stepwise. Analisis kedua ini dapat menghasilkan nilai Koefisien Determinasi yang lebih tinggi dari nilai sebelumnya, meskipun harus diterima bahwa nilai yang baru ini masih terlalu rendah. Meskipun begitu, beberapa fakta mengenai sistem kerja perusahaan dan latar belakang tenaga kerjanya, dapat dijadikan penjelasan mengenai hasil analisis yang telah dilakukan.
\end{abstract}

Kata kunci: produktivitas, regresi linier stepwise

\begin{abstract}
The longer the employment length, the more experience a person has on his or her job. $A$ person who has a high attendance at work, is considered a good worker. These two factors form the assumption that both employment length and work attendance, influence laborer productivity, either positively or negatively. As Labor productivity holds a lot of weight in relation to a company's health, conducting an analysis of a company's productivity, must not be based on assumptions, even though it's an acceptable one. Using multiple linear regression, a model was generated from data about the workforce. But, because the Coefficient of Determination value was less than satisfactory, an analysis was performed again on the data, this time using Stepwise Regression. The second analysis managed to produce a higher Coefficient of Determination value than the previous one, but it must accepted that the value remains too low. Though a few facts about the company's work system and labours history could provide some explanation on this result.
\end{abstract}

Keyword: productivity, stepwise linear regression

\section{Pendahuluan}

Sumber daya manusia (SDM) adalah salah satu faktor yang sangat penting bahkan tidak dapat dilepaskan dari sebuah organisasi, baik institusi maupun perusahaan. Ada dua pengertian bagi Sumber Daya Manusia. Yang pertama adalah usaha kerja maupun jasa yang dikontribusikan dalam kegiatan produksi.
Dalam hal lain Sumber Daya Manusia juga merupakan perwujudan kualitas kontribusi usaha seseorang dalam kurun waktu tertentu untuk menghasilkan sebuah produk atau jasa. Yang kedua, Sumber Daya Manusia dapat diartikan sebagai sesuatu yang berhubungan dengan manusia yang mampu melakukan pekerjaan yang memberikan jasa atau usaha kerja tersebut. 
Yang dimaksud dengan mampu melakukan perkerjaan adalah mampu melakukan kegiatan yang menghasilkan produk maupun jasa yang berhubungan dengan pemenuhan kebutuhkan masyarakat. Dengan kata lain mampu melakukan usaha yang bernilai ekonomis. Karyawan, tenaga kerja, atau buruh adalah sebutan-sebutan lain yang biasa digunakan bagi Sumber Daya Manusia (Sumarsono, 2003, p. 4).

Produktivitas adalah perbandingan jumlah keluaran dengan masukkan (Budiono, Jusuf, \& Pusparini, 2003, p. 263). Bagi sebuah perusahaan dalam industri padat karya, seperi sebuah pabrik, produktivitas tenaga kerja adalah bagian yang sangat penting. Kemampuan sebuah perusahaan dalam menghasilkan produk, harus bisa mengimbangi permintaan pasar.

Banyak sekali faktor-faktor yang bisa mempengaruhi kemampuan seseorang untuk melakukan sesuatu. Sejalan dengan itu, banyak juga faktor-faktor yang bisa mempengaruhi produktivitas seorang tenaga kerja. Jika produktivitas rendah, ini berarti perusahaan kurang maksimal dalam menggunakan tenaga kerjanya, sehingga keluaran yang dihasilkan tidak sepadan dengan biaya yang ditanggung (Hakim, 2011, p. 177).

Pengalaman kerja dapat diartikan sebagai jangka waktu atau seberapa lama seorang pekerja telah bekerja pada sebuah organisasi. (Alwi, 2001, p. 717). Semakin lama masa kerjanya, keterampilan pekerja dalam pekerjaannya akan meningkat berbanding lurus dengan produktivitasnya (Sulaeman, 2014, p. 99).

Absensi adalah ketidakhadiran tenaga kerja di sebuah organisasi atau perusahaan. Seorang yang memiliki tingat kehadiran tinggi, dianggap sebagai seorang pekerja yang baik. Prestasi kerja dipengaruhi secara sebagian oleh tingkat absensi (Dewi \& Mutiasari, 2007, p. 24).

Karena keoptimalan kinerja seorang pegawai mempengaruhi perkembangan perusahaan (Muttaqin, Nurijda, \& Tripalupi, 2014), maka dalam menganalisa produktivitas perusahaan secara keseluruhan, tidak bisa hanya berdasarkan asumsi-asumsi, yang memang harus diakui, sering terbukti kebenarannya. Untuk itu, perlu diteliti lebih lanjut, pengaruh masa kerja dan absensi terhadap produktivitas tenaga kerja.

\section{Metode Penelitian}

Objek penelitian adalah 159 tenaga kerja bagian linting dari PR. UD. Putra Bintang Timur, Malang. Dokumentasi data didapatkan secara resmi dari pihak perusahaan, dan dilakukan pula wawancara dengan pihak manajemen untuk mendapatkan informasi-informasi lainnya mengenai perusahaan dan tenaga kerjanya yang bisa digunakan dalam anailis penelitian.

Data yang digunakan adalah Masa Kerja (dalam bulan), Absensi (dalam persentase), dan Produktivitas (dalam linting/hari).

Sebelum dilakukan analisa regresi berganda, dilakukan uji asumsi klasik yang terdiri dari:

1. Uji Normalitas

Untuk menentukan apakah residual distribusi normal, digunakan uji Statistik Kolmogorov Smirnov. Nilai signifikansi > 0,05 menunjukkan residual berdistribusi normal (Ghozali, 2011, p. 160). Sebaliknya jika $<0,05$, distribusi tidak normal.

2. Uji Autokorelasi

Menggunakan uji Durbin-Watson. Melihat nilai Durbin-Watson (d), kemudian melihat tabel DW, diuji dengan aturan:

- $\mathrm{d}<\mathrm{dL}$ atau $\mathrm{d}>(4-\mathrm{dL}) \mathrm{H}_{0}$ ditolak (autokorelasi)

- $\mathrm{dU}<\mathrm{d}<(4-\mathrm{dU}) \mathrm{H}_{0}$ diterima (tidak autokorelasi)

- $\mathrm{dL}<\mathrm{d}<\mathrm{dU}$ atau $(4-\mathrm{dU})<\mathrm{d}<(4-\mathrm{dL})$ (tidak pasti)

3. Uji Multikolinieritas

Menggunakan nilai VIF dan Tolerance sebagai indikator untuk menentukan multikolinieritas (Raharjo, 2016, pp. 1-2).

- Jika nilai tolerance $>0,10$ maka dapat disimpulkan tidak terjadi multikolinieritas. Dan jika nilai tolerance <0,10 maka dapat disimpulkan terjadi multikolinieritas.

- Jika nilai VIF > 10, maka disimpulkan bahwa data yang diuji memiliki multikolinieritas. Jika nilai VIF $<10$, maka disimpulkan bahwa data yang diuji tidak memiliki multikolinieritas.

4. Uji Heteroskedastisitas

Untuk menguji apakah dalam model regresi terjadi ketidaksamaan varian dari residu satu pengamatan ke pengamatan yang lain (Septiana, 2015). 
Menggunakan uji Glejser, dilakukan dengan cara meregresikan antara variabel independen dengan nilai absolut residualnya. Jika nilai signifikansi antara variabel independen dengan absolut residual $>0,05$ maka menunjukkan tidak terjadi masalah heteroskedastisitas.

Setelah dilakukan analisa regresi berganda, dilakukan:

1. Uji F

Membandingkan nilai Fhitung denga Ftabel. Jika Fhitung > Ftabel, maka HO ditolak dan $\mathrm{H} 1$ diterima. Jika Fhitung < Ftabel, maka $\mathrm{H} 0$ diterima dan $\mathrm{H} 1$ ditolak.

2. Ujit

Membandingkan nilai Thitung denga Ttabel. Jika Thitung > Ttabel, maka HO ditolak dan $\mathrm{H} 1$ diterima. Jika Thitung < Ttabel, maka $\mathrm{H} 0$ diterima dan $\mathrm{H} 1$ ditolak.

Kemudian dilakukan stepwise regression untuk membuat model regresi baru yang lebih baik.

Stepwise regression adalah metode regresi berganda, yang secara sekaligus menghapus variabel-variabel bebas yang tidak penting. Stepwise regression pada dasarnya menjalankan regresi berganda beberapa kali, setiap kali menghapus variabel berkorelasi lemah. Hingga pada akhirnya tersisa variabel-variabel yang menjelaskan distribusi yang terbaik. Satusatunya persyaratan adalah bahwa data terdistribusi secara normal dan bahwa tidak ada korelasi antara variabel independen (dikenal sebagai kolinieritas). (School of Geography, University of Leeds, n.d., pp. 12). Dalam penggunaannya, metode ini memungkinkan variable bebas untuk masuk dan keluar dari model regresi, membuat langkah-langkah pembentukan model cukup banyak (Hanum, 2011, p. 1).

Forward stepwise regression dirancang untuk memilih dari sekelompok prediktor variabel, satu pada setiap tahap, yang memiliki semi-parsial $r$-square terbesar, dan karenanya membuat kontribusi terbesar R-square. (Ini juga adalah variabel yang memiliki nilai T terbesar).

Backwards stepwise regression bekerja secara sebaliknya. Jadi setiap variabel yang secara statistik tidak signifikan, yang membuat kontribusi terkecil tidak digunakan (yaitu variabel dengan semiparsial r-square terkecil, yang juga adalah variabel dengan nilai $T$ terkecil). Selanjutnya seperti itu, yang membuat kontribusi terkecil tidak digunakan. Prosedur dilaksanakan terus hingga semua variabel yang tersisa adalah yang signifikan secara statistik. (Watson, 2017, p. 2)

\section{Hasil dan Pembahasan}

Dengan memikirkan ketepatan dan kecepatan penelitian, maka semua pengujian dan perhitungan yang dilakukan terhadap data diterapkan menggunakan aplikasi IBM SPSS Statistics 21, untuk kemudian dianalisa hasilnya.

\subsection{Uji Asumsi Klasik}

1. Uji Normalitas

$\mathrm{H}_{0}$ : Residual terdistribusi normal

$\mathrm{H}_{1}$ : Residual terdistribusi tidak normal.

Jika nilai signifikansi lebih besar dari 0,05, $\mathrm{H}_{0}$ diterima, data berdistribusi normal. Jika nilai signifikansi lebih kecil dari $0,05, \mathrm{H}_{1}$ diterima, distribusi data tidak normal.

Tabel 1. One-Sample Kolmogorov-Smirnov Test

\begin{tabular}{|l|l|r|}
\hline \multicolumn{2}{|c|}{} & $\begin{array}{r}\text { Unstandardiz } \\
\text { ed Residual }\end{array}$ \\
\hline $\mathrm{N}$ & 159 \\
\hline $\begin{array}{l}\text { Normal } \\
\text { Parameters }\end{array}$ & Mean & .0000000 \\
\cline { 2 - 3 } & $\begin{array}{l}\text { Std. } \\
\text { Deviatio } \\
\mathrm{n}\end{array}$ & $\begin{array}{r}4.11185154 \mathrm{E} \\
2\end{array}$ \\
\hline $\begin{array}{l}\text { Most Extreme } \\
\text { Differences }\end{array}$ & $\begin{array}{l}\text { Absolut } \\
\mathrm{e}\end{array}$ & .062 \\
\cline { 2 - 3 } & Positive & .062 \\
\cline { 2 - 3 } & $\begin{array}{l}\text { Negativ } \\
\mathrm{e}\end{array}$ & -.044 \\
\hline Kolmogorov-Smirnov Z & .781 \\
\hline Asymp. Sig. (2-tailed) & .576 \\
\hline \multicolumn{2}{|c|}{ a. Test distribution is Normal. } \\
\hline \multicolumn{2}{|c|}{ Sumber: Hasil penelitian (2017) } \\
\hline
\end{tabular}

Berdasarkan uji KolmogorovSmirnov, diketahui nilai signifikansi adalah $0,576>0,05$, maka $\mathrm{H}_{0}$ diterima, data terdistribusi normal.

2. Uji Autokorelasi

$\mathrm{H}_{0}$ : Tidak terdapat autokorelasi

$\mathrm{H}_{1}$ : Terdapat autokorelasi

Uji autokorelasi biasanya hanya dilakukan pada data time series, tapi bukan berarti tidak bisa diterapkan pada data cross section juga. 


\begin{tabular}{|c|c|}
\hline \multicolumn{2}{|c|}{$\frac{\text { Tabel 2. Uji Autokorelasi }}{\text { Model Summary }^{\mathbf{b}}}$} \\
\hline Model & 1 \\
\hline$R$ & $.243^{\mathrm{a}}$ \\
\hline R Square & .059 \\
\hline Adjusted R Square & .047 \\
\hline $\begin{array}{l}\text { Std. Error of the } \\
\text { Estimate }\end{array}$ & 413.81256 \\
\hline Durbin-Watson & 1.833 \\
\hline \multicolumn{2}{|c|}{$\begin{array}{l}\text { a. Predictors: (Constant), Absensi, } \\
\text { MasaKerja }\end{array}$} \\
\hline \multicolumn{2}{|c|}{ b. Dependent Variable: Produktivitas } \\
\hline
\end{tabular}
Sumber: Hasil penelitian (2017)

Untuk mengetahui ada tidaknya autokorelasi dari satu observasi ke observasi lainnya, dibandingkan nilai DW hitung dengan nilai tabel DW signifikansi 0,05 . Jumlah $N=159$, jumlah variable independen $\mathrm{k}=2$, Nilai Durbin-Watson = 1,833 .

$\mathrm{dL}=1,706$

$\mathrm{dU}=1,760$

$4-\mathrm{dU}=2,240$

$4-\mathrm{dL}=2,294$

Karena dU $<$ nilai DW $<(4-\mathrm{dU})$, maka $\mathrm{HO}$ diterima, tidak terdapat autokorelasi dalam model regresi.

\section{Uji Multikolinieritas}

Nilai VIF dan Tolerance adalah indikator untuk menentukan multikolinieritas. Jka nilai VIF $<10$ dan atau nilai Tolerance $>0,01$ maka dapat disimpulkan bahwa tidak terdapat multikolinieritas.

Tabel 3. Uji Multikolinieritas

\begin{tabular}{|l|l|r|r|}
\hline \multicolumn{3}{|c|}{ Coefficients $^{\mathrm{a}}$} \\
\hline \multirow{2}{*}{ Model } & \multicolumn{2}{|c|}{$\begin{array}{c}\text { Collinearity } \\
\text { Statistics }\end{array}$} \\
\cline { 3 - 4 } \multicolumn{2}{|c|}{} & Tolerance & VIF \\
\hline \multirow{2}{*}{1} & (Constant) & & \\
\cline { 2 - 4 } & MasaKerja & .975 & 1.025 \\
\cline { 2 - 4 } & Absensi & .975 & 1.025 \\
\hline \multicolumn{2}{|c|}{ a. Dependent Variable: Produktivitas } \\
\hline
\end{tabular}

Sumber: Hasil penelitian (2017)

Tolerance $=0,975>0,01$

$\mathrm{VIF}=1,025<30$

Tidak ada kolinieritas antar variable bebas dalam model regresi.
Tabel 4. Uji Heteroskedastisitas

\begin{tabular}{|c|c|c|c|c|c|}
\hline \multirow{3}{*}{\multicolumn{2}{|c|}{ Model }} & \multicolumn{4}{|c|}{ Coefficients $^{a}$} \\
\hline & & \multicolumn{2}{|c|}{$\begin{array}{l}\text { Unstandardized } \\
\text { Coefficients }\end{array}$} & \multirow[t]{2}{*}{$\mathrm{t}$} & \multirow[t]{2}{*}{ Sig } \\
\hline & & B & $\begin{array}{l}\text { Std. } \\
\text { Error }\end{array}$ & & \\
\hline \multirow[t]{3}{*}{1} & $\begin{array}{l}\text { (Consta } \\
\text { nt) }\end{array}$ & $\begin{array}{r}420.81 \\
7 \\
\end{array}$ & $\begin{array}{r}124.54 \\
5\end{array}$ & $\begin{array}{r}3.37 \\
9\end{array}$ & $\begin{array}{r}.00 \\
1\end{array}$ \\
\hline & $\begin{array}{l}\text { MasaKer } \\
\text { ja }\end{array}$ & -1.037 & .702 & $\begin{array}{r}1.47 \\
9\end{array}$ & $\begin{array}{r}.14 \\
1\end{array}$ \\
\hline & Absensi & -.732 & 1.400 & .523 & $\begin{array}{r}.60 \\
2 \\
\end{array}$ \\
\hline
\end{tabular}

4. Uji Heteroskedastisitas

Jika nilai signifikansi > 0,05 maka tidak terjadi gejala Heteroskedastisitas.

MasaKerja $\left(\mathrm{X}_{1}\right)=0,141$

Absensi $\left(X_{2}\right)=0,602$

Kedua nilai variable lebih besar dari 0,05.

Tidak ada gejala heteroskedastisitas.

\subsection{Analisis Regresi Linier Berganda}

1. Koefisien Determinasi

Berdasarkan Tabel 5 Koefisien

Determinasi ( $R$ Square) $=0,059$. Tapi karena kita menggunakan lebih dari 1 variabel independen, untuk Koefisien Determinasi dugunakan Ajusted $R$ Square $=0,047$. Artinya $4,7 \%$ dari nilai variabel terikat $Y$ (Produktivitas) dipengaruhi oleh variable independen, yaitu MasaKerja (X1) dan Absensi (X2). Sedangkan $95,3 \%$ dari nilai variabel terikat Y (Produktivitas) dipengaruhi oleh variable-variabel lain.

Tabel 5. Koefisien Determinasi

\begin{tabular}{|l|c|c|r|r|}
\hline \multicolumn{5}{|c|}{ Model Summary } \\
\hline $\begin{array}{l}\text { Mode } \\
I\end{array}$ & $\mathrm{R}$ & $\begin{array}{c}\mathrm{R} \\
\text { Squar } \\
\mathrm{e}\end{array}$ & $\begin{array}{c}\text { Adjuste } \\
\mathrm{d} \mathrm{R} \\
\text { Square }\end{array}$ & $\begin{array}{c}\text { Std. Error } \\
\text { of the } \\
\text { Estimate }\end{array}$ \\
\hline 1 & $\begin{array}{r}.243 \\
\mathrm{a}\end{array}$ & .059 & .047 & $\begin{array}{r}413.8125 \\
6\end{array}$ \\
\hline
\end{tabular}

a. Predictors: (Constant), Absensi, MasaKerja

Sumber: Hasil penelitian (2017) 


\begin{tabular}{|c|c|c|c|c|}
\hline \multicolumn{5}{|c|}{$\frac{\text { Tabel 6. Regresi \& Uji t }}{\text { Coefficients }^{\mathrm{a}}}$} \\
\hline \multicolumn{2}{|c|}{ Model } & Unstandardiz & $t$ & Sig. \\
\hline \multirow[t]{3}{*}{1} & $\begin{array}{l}\text { (Constan } \\
\text { t) }\end{array}$ & 2255.831 & $\begin{array}{r}10.99 \\
4\end{array}$ & $\begin{array}{r}.00 \\
0\end{array}$ \\
\hline & $\begin{array}{l}\text { MasaKerj } \\
\text { a }\end{array}$ & -.421 & -.364 & $\begin{array}{r}.71 \\
6\end{array}$ \\
\hline & Absensi & 7.206 & 3.124 & $\begin{array}{r}.00 \\
2\end{array}$ \\
\hline
\end{tabular}

Sumber: Hasil penelitian (2017)

\section{Persamaan Regresi}

Dari Tabel 6, didapatkan persamaan regresi:

$$
Y=2255,831-0,421 X_{1}+7,206 X_{2}
$$

Dari persamaan tersebut dapat diartikan:

- Produktivitas $(\mathrm{Y})$ akan menurun sebesar 0,421 (Lintingan/hari), jika Masa Kerja $\left(X_{1}\right)$ naik 1 (bulan). Dengan asumsi Absensi $\left(X_{2}\right)$ tetap.

- Produktivitas $(Y)$ akan meningkat sebesar 7,206 (Lintingan/hari), jika Absensi $\left(X_{2}\right)$ naik 1 (persen). Dengan asumsi Masa Kerja $\left(\mathrm{X}_{1}\right)$ tetap.

3. Uji F

$\mathrm{H}_{0}$ : Keseluruhan variable independen (bebas) tidak mempunyai pengaruh yang berarti terhadap variable terikat

$\mathrm{H}_{1}$ : Keseluruhan variable independen (bebas) mempunyai pengaruh yang berarti terhadap variable terikat

Tabel 7. Uji F

\begin{tabular}{|c|c|c|c|c|c|}
\hline \multicolumn{6}{|c|}{ ANOVA $^{\mathrm{b}}$} \\
\hline \multicolumn{2}{|c|}{ Model } & Sum of & $d f$ & $F$ & Sig. \\
\hline 1 & $\begin{array}{l}\text { Regressi } \\
\text { on }\end{array}$ & $\begin{array}{r}1674025 \\
973\end{array}$ & 2 & $\begin{array}{r}4.88 \\
8\end{array}$ & $\begin{array}{l}.00 \\
9^{\mathrm{a}}\end{array}$ \\
\hline & Residual & $2.671 \mathrm{E} 7$ & $\begin{array}{r}15 \\
6\end{array}$ & & \\
\hline & Total & $2.839 \mathrm{E} 7$ & $\begin{array}{r}15 \\
8 \\
\end{array}$ & & \\
\hline
\end{tabular}

a. Predictors: (Constant), Absensi, MasaKerja

b. Dependent Variable: Produktivitas Sumber: Hasil penelitian (2017)

Untuk ini bisa dilakukan dengan uji $F$. Membandingkan nilai $F_{\text {hitung }}$ denga $F_{\text {tabel }}$. Jika $F_{\text {hitung }}>F_{\text {tabel }}$, maka $\mathrm{H} 0$ ditolak dan $\mathrm{H} 1$ diterima. Jika $F_{\text {hitung }}<F_{\text {tabel }}$, maka $\mathrm{HO}$ diterima dan $\mathrm{H} 1$ ditolak. Dengan menggunakan $\alpha=0,05$ dan degree of freedom $(k, n-k-1)=2,156$, didapatkan:

$F_{\text {hitung }}=4,888$

$\mathrm{F}_{\text {tabel }}=3.0718$

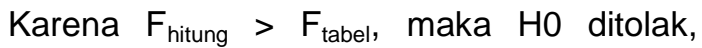
Keseluruhan variable independen (bebas) mempunyai pengaruh yang berarti terhadap variable terikat.

Jika menggunakan SPSS, cukup dengan melihat nilai Signifikansi (Sig.). Jika Sig. > 0,05, maka H0 diterima, dan jika Sig. $<0,05$, maka $\mathrm{HO}$ ditolak. Dilihat di tabel x.x, Sig. = $0,009<0,05$. Maka sama dengan kesimpulan di atas $\mathrm{HO}$ ditolak, Keseluruhan variable independen (bebas) mempunyai pengaruh yang berarti terhadap variable terikat.

\section{Uji t}

Tabel 6.

Uji t untuk $X_{1}$ (MasaKerja). Lihat

- $\mathrm{H}_{0}$ : Variable independen $\mathrm{X}_{1}$ (MasaKerja) tidak mempunyai pengaruh parsial yang berarti terhadap variable terikat.

- $\mathrm{H}_{1}$ : Variable independen $\mathrm{X}_{1}$ (MasaKerja) mempunyai pengaruh parsial yang berarti terhadap variable terikat.

Membandingkan nilai $T_{\text {hitung }}$ denga $T_{\text {tabel }}$. Jika $T_{\text {hitung }}>T_{\text {tabel }}$, maka $\mathrm{HO}$ ditolak dan $\mathrm{H} 1$ diterima. Jika $\mathrm{T}_{\text {hitung }}<\mathrm{T}_{\text {tabel }}$, maka $\mathrm{HO}$ diterima dan $\mathrm{H} 1$ ditolak. Dengan menggunakan $\alpha=0,05$, degree of freedom (n-k-1), dan menggunakan two-tailed test, maka:

$\mathrm{T}_{\text {tabel }}=(\alpha / 2, \mathrm{n}-\mathrm{k}-1)$

$\mathrm{T}_{\text {tabel }}=(0,025,156)$

$\mathrm{T}_{\text {tabel }}=1,960$

$T_{\text {hitung }}=-0,364$

Karena $\mathrm{T}_{\text {hitung }}<\mathrm{T}_{\text {tabel }}$, maka $\mathrm{H} 0$ diterima. Variable independen X1 (MasaKerja) tidak mempunyai pengaruh parsial yang berarti terhadap variable terikat

Jika menggunakan SPSS, cukup dengan melihat nilai Signifikansi (Sig.). Jika Sig. > 0,05, maka HO diterima, dan jika Sig. $<0,05$, maka $\mathrm{H} 0$ ditolak.

Dilihat di tabel 6, Sig. $=0,716>$ 0,05 . Maka sama dengan kesimpulan di atas HO diterima, Variable independen X1 (MasaKerja) tidak mempunyai pengaruh parsial yang berarti terhadap variable terikat 
Uji t untuk $\mathrm{X}_{2}$ (Absensi). Lihat Tabel 6.

- $\mathrm{H}_{0}$ : Variable independen $\mathrm{X}_{2}$ (Absensi) tidak mempunyai pengaruh parsial yang berarti terhadap variable terikat

- $\mathrm{H}_{1}$ : Variable independen $\mathrm{X}_{2}$ (Absensi) mempunyai pengaruh parsial yang berarti terhadap variable terikat

Membandingkan nilai $T_{\text {hitung }}$ denga $T_{\text {tabel. }}$. Jika $T_{\text {hitung }}>T_{\text {tabel }}$, maka $\mathrm{H} 0$ ditolak dan $\mathrm{H} 1$ diterima. Jika $\mathrm{T}_{\text {hitung }}<\mathrm{T}_{\text {tabel, }}$ maka $\mathrm{H} 0$ diterima dan $\mathrm{H} 1$ ditolak. Dengan menggunakan $\alpha=0,05$, degree of freedom $(n-k-1)$, dan menggunakan two-tailed test, maka:

$\mathrm{T}_{\text {tabel }}=(\alpha / 2, \mathrm{n}-\mathrm{k}-1)$

$T_{\text {tabel }}=(0,025,156)$

$\mathrm{T}_{\text {tabel }}=1,960$

$\mathrm{T}_{\text {hitung }}=3,124$

Karena $\mathrm{T}_{\text {hitung }}>\mathrm{T}_{\text {tabel }}$, maka $\mathrm{HO}$ ditolak dan $\mathrm{H} 1$ diterima. Variable independen X2 (Absensi) mempunyai pengaruh parsial yang berarti terhadap variable terikat.

Jika menggunakan SPSS, cukup dengan melihat nilai Signifikansi (Sig.). Jika Sig. > 0,05, maka HO diterima, dan jika Sig. $<0,05$, maka $\mathrm{H} 0$ ditolak.

Dilihat di tabel 6, Sig. $=0,02<0,05$. Maka sama dengan kesimpulan di atas $\mathrm{HO}$ ditolak dan $\mathrm{H} 1$ diterima. Variable independen X2 (Absensi) mempunyai pengaruh parsial yang berarti terhadap variable terikat.

\subsection{Memperbaiki Model Regresi Menggunakan Stepwise Regression}

Karena variable independen $X_{1}$ (MasaKerja) tidak mempunyai pengaruh parsial yang signifikan terhadap variable terikat (Produktivitas), maka akan dihilangkan dari model regresi. Variabel terikat yang digunakan menjadi hanya satu, yaitu $\mathrm{X}_{2}$ (Absensi). Menjadikan persamaan regresi dari linear berganda ke linear sederhana.

Tabel 8. Koefisien Determinasi Stepwise

\begin{tabular}{|l|c|c|c|r|}
\hline \multicolumn{5}{|c|}{ Model Summary } \\
\hline $\begin{array}{l}\text { Mode } \\
\text { I }\end{array}$ & $\mathrm{R}$ & $\begin{array}{c}\mathrm{R} \\
\text { Squar } \\
\mathrm{e}\end{array}$ & $\begin{array}{c}\text { Adjuste } \\
\mathrm{d} \mathrm{R} \\
\text { Square }\end{array}$ & $\begin{array}{r}\text { Std. Error } \\
\text { of the } \\
\text { Estimate }\end{array}$ \\
\hline 1 & $\begin{array}{r}241 \\
\mathrm{a}\end{array}$ &, 058 &, 052 & $\begin{array}{r}412,6678 \\
7\end{array}$ \\
\hline \multicolumn{4}{|c|}{ a. Predictors: (Constant), Absensi } \\
\hline \multicolumn{4}{|c|}{ b. Dependent Variable: Produktivitas } \\
\hline
\end{tabular}
Sumber: Hasil penelitian (2017)
Berdasarkan tabel 8 Koefisien Determinasi ( $R$ Square) $=0,058$. Karena hanya ada 1 variabel independen, digunakan angka ini untuk Koefisien Determinasi .Artinya 5,8\% dari nilai variabel terikat $\mathrm{Y}$ (Produktivitas) dipengaruhi oleh variable independen Absensi (X). Sedangkan $94,2 \%$ dari nilai variabel terikat Y (Produktivitas) dipengaruhi oleh variablevariabel lain.

Perhatikan: Nilai koefisien Derteminasi meningkat setelah menggunakan Stepwise Regression. Dari yang sebelumnya $4,7 \%$, menjadi $5,8 \%$

Tabel 9. Regresi \& Uji t Stepwise

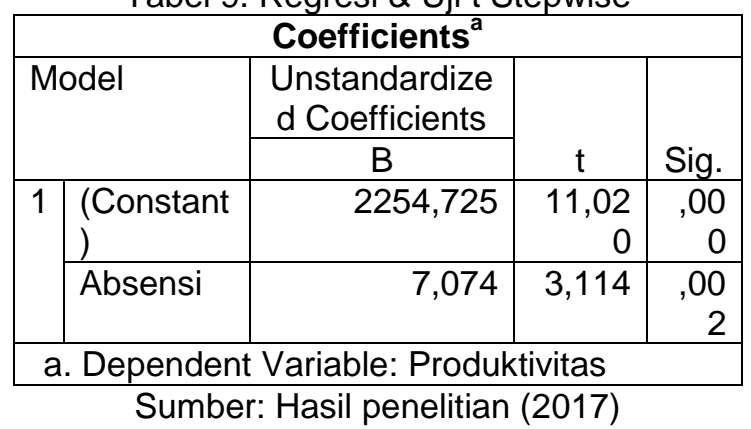

Dari tabel 9, didapatkan persamaan regresi:

$$
Y=2254,725+7,074 X
$$

diartikan:

Dari persamaan di atas dapat

Produktivitas $(Y)$ akan meningkat sebesar 7,074 (Lintingan/hari), jika Absensi (X) naik 1 (persen).

Tabel 10. Uji F Stepwise

\begin{tabular}{|l|l|r|r|r|r|}
\hline \multicolumn{7}{|c|}{ ANOVA $^{\text {a }}$} \\
\multicolumn{2}{|l|}{ Model } & $\begin{array}{c}\text { Sum of } \\
\text { Squares }\end{array}$ & df & F & Sig. \\
\hline \multirow{2}{|l|}{1} & Regressi & 1651317,4 & 1 & 9,69 &, 00 \\
& on & 09 & & 7 & $2^{\text {b }}$ \\
\cline { 2 - 6 } & Residual & 26736279, & 15 & & \\
& & 022 & 7 & & \\
\cline { 2 - 6 } & Total & 28387596, & 15 & & \\
& & 431 & 8 & & \\
\hline
\end{tabular}

a. Dependent Variable: Produktivitas

b. Predictors: (Constant), Absensi Sumber: Hasil penelitian (2017)

- $\mathrm{H}_{0}$ : Variable independen X (Absensi) tidak mempunyai pengaruh yang berarti terhadap variable terikat

- $\mathrm{H}_{1}$ : Variable independen X (Absensi) mempunyai pengaruh yang berarti terhadap variable terikat 
Untuk uji $F$, dilihat di tabel 10, Sig. = $0,002<0,05$. Maka HO ditolak, Variable independen $X$ (Absensi) mempunyai pengaruh yang berarti terhadap variable terikat.

Untuk uji t, dilihat di tabel 9, Sig. $=0,002$ $<$ 0,05. Maka H0 ditolak, Variable independen $X$ (Absensi) mempunyai pengaruh yang berarti terhadap variable terikat.

\subsection{Pertimbangan Variabel Yang Tidak Dihitung}

Dalam wawancara dengan pihak manajemen, ditemukan kemungkinan bahwa angka produktivitas tenaga kerja yang didapatkan, tidak mencerminkan kemampuan maksimal produktivitas mereka. Dalam tiap hari kerja, setiap tenaga kerja diberikan "Paket" untuk melinting rokok berjumlah 2000 lintingan (batang). Jika seorang pekerja menyelesaikan paketnya sebelum jam kerja berakhir, yang umumnya memang seperti itu, dia bisa meminta atau diberikan paket pekerjaan lagi yang disesuaikan dengan sisa waktu kerja hari itu dan kebutuhan produksi berjumlah minimal kelipatan 250 lintingan (batang). Seorang tenaga kerja yang mendapatkan paket pekerjaan harus menyelesaiakan paket itu, meskipun telah melewati akhir jam kerja untuk hari itu. Jadi sistem 'paket' ini, mungkin bisa menjadi penyebab catatan produktivitas tenaga kerja kurang mencerminkan produktivitas maksimal mereka, dan mempengaruhi model regresi yang dihasilkan.

Ada faktor besar yang mempengaruhi variabel Masa Kerja. Jadi meskipun masa kerja di perusahaan belum lama, karena banyak pabrik-pabrik serupa di daerah yang sama, besar kemungkinan seorang tenaga kerja baru telah memiliki pengalaman pekerjaan yang sama di perusahaan lain.

Asumsi-asumsi ini mungkin bisa dijadikan pertimbangan tentang mengapa model regresi yang dihasilkan memiliki nilai Koefisien Determinasi yang sangat kecil.

\section{Kesimpulan}

Uji regresi berganda yang dilakukan menghasilkan model regresi yang memiliki satu variable bebas yang tidak memiliki pengaruh yang signifikan. Menggunakan Stepwise Regression, model regresi awal diubah menjadi model regresi baru yang mempunyai nilai Koefisien Determinasi lebih besar. Dengan ini dapat disimpulkan bahwa Masa Kerja tidak memiliki pengaruh yang cukup signifikan terhadap produktivitas buruh. Dan Tingkat absensi memberikan pengaruh $5,8 \%$ terhadap produktivitas buruh.

Pengembangan lebih lanjut bisa dilakukan dengan menganalisa dan meneliti variable-variabel independen lain yang memiliki pengaruh signifikan terhadap produktivitas buruh. Dengan begitu besarnya persentase pengaruh variabel yang tidak dibahas dalam penelitian ini $(94,2 \%)$, hal ini adalah bagian utama yang harus dilakukan dalam usaha menghasilkan penelitian yang lebih baik.

Perlu diperhatikan juga, pada dasarnya jika tujuan penelitian adalah untuk menginferensi kausalitas, maka penggunaa stepwise regression bisa menjadi kurang tepat. Karena stepwise regression lebih mengutamakan kekuatan prediktif dari model yang dihasilkannya.

Stepwise regression mudah dilakukan secara manual jika variabel prediktor sedikit seperti dalam penelitian ini. Untuk penelitian yang lebih besar, dengan jumlah variabel prediktor yang banyak, gunakan alat statistika seperti SPSS.

\section{Referensi}

Alwi, S. (2001). Manajemen Sumber Daya Manusia: Strategi Keunggulan Kompetitif (Edisi Pertama). Yogyakarta: BPFE.

Budiono, A., Jusuf, R., \& Pusparini, A. (2003). BUNGA RAMPAI HIPERKES \& KK edisi kedua(revisi). Semarang: BP Universitas Diponegoro.

Dewi, S., \& Mutiasari, M. (2007). Pengaruh Masa Kerja, Tingkat Absensi Dan Perputaran Tugas Kerja Terhadap Prestasi Kerja Pegawai Kantor Distrik Navigasi Kelas lii Cilacap. Jurnal Dinamika Ekonomi \& Bisnis Vol 4, No 2, 24.

Ghozali, I. (2011). Aplikasi Analisis Multivariate Dengan Program IBM SPSS 19 (edisi kelima.). Semarang: BP Universitas Diponegoro. 
Hakim, A. K. (2011). Pengaruh Kompensasi Dan Motivasi Terhadap Produktivitas Kerja Pegawai. Jurnal Manajemen \& Bisnis Vol 11, 177.

Hanum, H. (2011). Perbandingan Metode Stepwise, Best Subset Regression, dan Fraksi dalam Pemilihan Model Regresi Berganda Terbaik. Jurnal Penelitian Sains Vol 14 No 2, 1.

Muttaqin, A., Nurijda, M., \& Tripalupi, L. E. (2014). Pengaruh Latar Belakang Pendidikan, Masa Kerja Dan Motivasi Kerja Karyawan Terhadap Kinerja Karyawan Pada Pt. Indocitra Jaya Samudra Tahun 2013. Jurnal Pendidikan Ekonomi Undiksha.

Raharjo, S. (2016). Uji Asumsi Klasik. Retrieved from SPSS Indonesia: http://www.spssindonesia.com/searc h/label/Uji\%20Asumsi\%20Klasik

School of Geography, University of Leeds. (n.d.). Stepwise linear regression. Retrieved from School Of Geography:

http://www.geog.leeds.ac.uk/course s/other/statistics/spss/stepwise/

Septiana, V. A. (2015). Pengaruh Faktor Masa Kerja, Kompensasi Dan Pendidikan Terhadap Motivasi Kerja Pegawai Dinas Bina Marga Provinsi Jawa Tengah Dengan Produktivitas Kerja Sebagai Variabel Intervening. Journal of Management.

Sulaeman, A. (2014). Pengaruh Upah dan Pengalaman Kerja terhadap Produktivitas Karyawan. Jurnal Ekonomi Trikonomika, 99.

Sumarsono, S. (2003). Ekonomi Manajemen Sumberdaya Manusia Dan Ketenagakerjaan. Yogyakarta: Graha IImu.

Watson, P. (2017, 02 07). What is the difference between hierarchical and stepwise regressions? Retrieved from MRC Cognition and Brain Sciences Unit: http://imaging.mrccbu.cam.ac.uk/statswiki/FAQ/hier 